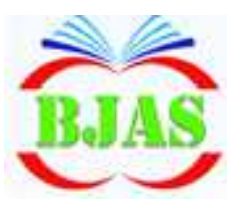

Available online at http://journal.bajas.edu.iq

College of Agriculture, University of Basrah

DOi:10.21276/basjas
Basrah Journal

of Agricultural

Sciences

ISSN $1814-5868$

Basrah J. Agric. Sci., 31(2): 1-10, 2018

E-ISSN: 2520-0860

\title{
Use the Mixture of Rice Straw and the Conocarpus erectus L., 1758 Leaves as the Medium of the Biofilter to Reduce the Ammonia Emitted from Poultry Houses
}

\author{
Assad Y. Khudher ${ }^{1 *}$ Riyed K. Mossa $^{2}$ \& Jaffer M. Jassim ${ }^{2}$ \\ 1 Department of Agricultural Mechanization, College of Agriculture, University of Basrah \\ 2 Department of Animal Production, College of Agriculture, University of Basrah \\ *Corresponding author e-mail: asadyousif22@yahoo.com \\ Received 8 October 2018; Accepted 3 December 2018; Available online 29 December 2018
}

\begin{abstract}
Poultry houses contribute $93 \%$ of the total amount of ammonia gas emitted from production facilities. The study aims to evaluate the efficiency of the biofilter for reducing environmental pollution by ammonia gas and using local and cheap materials. Two field experiments were conducted, A chicken (Ross 308, weigh $44.5 \mathrm{~g}$ ) was raised in 35 days. Experiment unit dimensions are $1.2 \times 1.5 \times 2.5$ length, width and height and each one of them was connected with a biofilter from the outside by air transport channel. The first experiment of three stocking densities $(14,16,18)$ birds $/ \mathrm{m}^{2}$ and three replicates. The second experiment included the use of one SD (14 bird $\left.\backslash \mathrm{m}^{2}\right), 3$ mixtures of rice straw and the conocarpus leaves as the medium of the Biofilter and three replicates. The efficiency of the biofilter (mixture of 0.30 Conocarpus leaves with 0.70 rice straw) was $91 \%$. The efficiency of the Biofilter was about $91.7 \%$ when media 0.25 of Conocarpus with 0.75 straw rice and characterized by a high content of total fungi compared to the other two.
\end{abstract}

Keywords: Ammonia gas, Biofilter, Poultry house, Broiler.

\section{Introduction}

Poultry houses contribute $93 \%$ of the total amount of ammonia gas emitted from production facilities. Ammonia is among the sources of environmental pollution locally, regionally and globally (Okoli et al., 2004). Estimates of the manure excreted by 1000 birds per day (based on average daily live weights during the bird's production cycle) are approximately $120 \mathrm{~kg}$ for layer chickens, $80 \mathrm{~kg}$ for meet chickens (Williams et al., 1999). Ammonia gas is derived from the droppings of birds that contain nitrogen in the form of uric acid Then by microbial fermentation processes turns into ammonium ion $(\mathrm{NH} 4+)$ with moisture content, temperature and $\mathrm{pH}$, ammonium is converted to ammonia gas (Carlile, 1984; Kostadinova et al., 2014).

In Europe, the regulations set out the socalled impact factor, which refers to the amount of ammonia gas that is not allowed to be exceeded and released by the air by poultry 


\section{Khudher et al. / Basrah J. Agric. Sci., 31 (2): 1-10, 2018}

projects. For example, select the effect factor of 45 and $80 \mathrm{~g} / \mathrm{bird}$ annually in the Netherlands and Germany respectively (Ogink \& Koerkamp, 2001).

There are different techniques for handling the emission of pollutants from animal production facilities. One of the most prominent techniques used is the biofilter. Two decades ago, researchers have praised the use of biofilters as a way to treat ammonia (Hong \& Park, 2004; La Pagans et al., 2005). By comparing biofilter technology with other technologies, (Maia et al., 2012); it has the potential to treat a large volume of polluted air and at low concentrations in an efficient manner (Chen \& Hoff, 2009; Devinny \& Webster, 2017).

When the passage of the polluted air through the damp filter pad is taken from the mechanical ventilation fans, the process of absorbing the pollutant begins by media and analysing the pollutant by developing microbes in the media, Pagans et al. (2007) showed that the contribution of biodegradation to ammonia is less than the absorption process. The main products of this treatment are gases, carbon dioxide, some salts, nitrate and nitrite ions by nitrification.

The efficiency of the biofilter in reducing ammonia emissions ranged from $43.4 \%$ to $100 \%$. There was a marked contrast in the results of the research, even in the tests performed on the same type of biofilter media. The efficiency of the wood bark was ranged from 45.8 to $99.8 \%$. Organic materials performed better than inorganic materials when used in the filter because they encourage the growth of microorganisms (Kim et al., 2000) .

The better porosity of the media biofilter and the less concentration of dust in the air, the pressure resulting from the filler resistance will decrease as the air passes through it. Nicolai \& Janni (2001) found that the pressure drop increased by increasing the amount of compost to wood chips by closing the filling pores and recommending $20-30 \%$ compost based on weight to $70-80 \%$ wood chips (Yang et al., 2011).

The volumetric distribution of media biofilter parts leads to increase pressure drop and consequent negative impact on filter efficiency in ammonia removal (Nicolai et al., 2006).

Prokop \& Bohn (1985) recorded a good performance for the filter at a moisture content of $40-60 \%$ in Peat moss and $40-50 \%$ in compost $35-65 \%$ In the covering of bark as well as the compost mixture and bark chips, and can be as high as $60-80 \%$ in media's such as pine bark and perlite (Chang et al., 2004).

We did not notice the use of techniques to treat ammonia gas pollution from poultry fields in Iraq, despite the expansion of poultry projects in recent years. Therefore, the following objectives were identified in the current study:

Evaluation of the efficiency of low-cost biofilter in reducing the emission of ammonia gas under the influence of different concentrations of ammonia and evaluation of the effect mixture of the biofiller media materials (Conocarpus leaves with the rice straw) on the efficiency of the biofilter in reducing ammonia gas emissions to the external environment.

A large number of substances were used as a feedstock for the biofilter (Table 1).

\section{Materials and Methods:}

Biofilter design: The design calculations were based on the use of locally available, inexpensive and untested materials. So we mixed the Conocarpus leaves with the rice straw.

$$
\mathrm{V}=\mathrm{Q} \times \mathrm{EBCT} \text {. }
$$

Where, $\mathrm{V}=$ Biofilter size; $\mathrm{Q}=$ Ventilation rate; $\mathrm{EBCT}=$ Empty Bed Contact Time

$$
\mathrm{Q}=0.07 \mathrm{~m}^{3} \backslash \mathrm{s} \text { Was selected according to }
$$
the need of birds $/ \mathrm{m}^{2}$

$\mathrm{EBCT}=3$ second (Schmid, et al., 2004)

$$
\mathrm{TPD}=\mathrm{UPD} \times \mathrm{D} \ldots . .(2)
$$

Where, $\mathrm{TPD}=$ Total Pressure Drop $\left(\mathrm{mmH}_{2} \mathrm{O}\right) ; \mathrm{UPD}=$ Unit Pressure Drop; $\mathrm{D}=$ Depth of media

$$
\mathrm{D}=0.25 \mathrm{~m} \text { (Schmid et al., 2004) }
$$


Khudher et al. / Basrah J. Agric. Sci., 31 (2): 1-10, 2018

Table (1): Types of media biofilter and its efficiency in reducing the emission of ammonia.

\begin{tabular}{|c|c|c|}
\hline Media & RE \% * & Source \\
\hline compost & 99.9 & (Maia et al., 2012) \\
\hline Wood chips & 58 & (Hoff et al., 2009) \\
\hline Wood chips & $99.4-99.8$ & (Chen \& Hoff, 2009) \\
\hline Wood chips & 45.8 & (Lim et al., 2012) \\
\hline Western ceder (Wood chips) & 43.4 & \multirow[t]{4}{*}{ (Chen \& Hoff 2012) } \\
\hline Hard wood (Wood chips) & 74 & \\
\hline Fuyolite & $55-100$ & \\
\hline Ceramics & $50-100$ & \\
\hline Polyurethane bed & $97-99$ & (Ryu et al., 2011) \\
\hline Lava rock & 56 & (Akdeniz et al., 2011) \\
\hline 40:40:60 Mixture of compost soil, peat and Oak & 88.4 & \multirow{2}{*}{$\begin{array}{l}\text { (Lawniczek-Walczyk } \\
\text { et al., 2013) }\end{array}$} \\
\hline 40:40:60 Mixture of compost soil, peat and Coconut fiber & 89.7 & \\
\hline 20:80 Mixture of manure fertilizer and rick husk & $99-100$ & $\begin{array}{c}\text { (Jinanan \& } \\
\text { Leungprasert 2015) }\end{array}$ \\
\hline
\end{tabular}

*RE\% Reduction of Ammonia Gas (Biofilter efficiency).

$$
\mathrm{UAR}=\mathrm{Q} \div \mathrm{A} \ldots . .(5)
$$

$\mathrm{UPD}=8.82 \times 10^{11} \times(\text { percent voids })^{-8.6} \times \mathrm{UAR}$ $1.27 \ldots \ldots \ldots . . .(3)$

Where, UAR $=$ Unit Air Flow Ratio $\left(\mathrm{m}^{3} \backslash \mathrm{m}^{2}\right)$ Percent voids of media Biofilter $=$ (porosity $\%)$.

The bucket method was used (Schmid et al., 2004), where a bucket was filled with a sample of media up to $1 / 3$ bucket and the bucket was dropped ten times from a height of $15 \mathrm{~cm}$ to the ground, then complete the bucket by $2 / 3$ size of the sample media and dropped for ten times as the first time, after that add the bucket completely and then dropped for ten times until the media filled the size of the bucket completely, finally add the water leisurely above the media in the bucket until the water reached the edge of the upper bucket and with the measuring of the amount of water added and then calculated the porosity $\%$ by the following equation:

Percent voids $=\frac{\text { Volume of water added }}{20 \text { liters }}$ $\mathrm{x} 100 \ldots . . .(4)$

Percent voids $=$ porosity $\%$; volume of water added (litter); 20 litres $=$ pile size

Where, $\mathrm{A}=$ Area of media Biofilter

$\mathrm{A}=\mathrm{V} \backslash \mathrm{D} \ldots \ldots .(6)$

Results of design calculations:

$\mathrm{V}=0.09 \mathrm{~m}^{3}, \mathrm{~A}=0.36 \mathrm{~m}^{2}, \mathrm{TPD}=2.7 \mathrm{mmH}_{2} \mathrm{O}$

Using the opposite wood and wire mesh with circular channel section to move the air from the ventilator fan to the position under the media, the medium height from the ground surface was $30 \mathrm{~cm}$. The biofilter media were wet during the experiment period by a bucket.

\section{Conducting experiments}

Two field experiments were conducted in the poultry field of the Agricultural Research Station, College of Agriculture, University of Basrah. The first experiment aimed to evaluate the efficiency of the biofilter with different concentrations of ammonia gas using different densities of birds, lasted 35 days from $20^{\text {th }}$ November 2017.

The experiment plan included the use of three densities of birds $(14,16,18)$ birds $/ \mathrm{m}^{2}$ 
and three replicates where each was allocated to dimensions of $1.2 \times 1.5 \times 2.5$ length, width, height and all were connected with a biofilter from the outside by air transport channel. A total of 234 chickens (Ross 308, weigh 44.5 g) were raised 35 days. The floor was sprinkled with wood shavings $7 \mathrm{~cm}$ thick until the age of the birds were 21 days and then completed to $10 \mathrm{~cm}$ thickness for the rest of the breeding period. The electric heater (1200 W) was used in the hall to heat the furnace and control the temperature and humidity (Electronical devices) during the last week of experiment and used lighting 24 hours a day.

The second experiment lasted 35 days from $18 / 3 / 2018$ to $21 / 4 / 2018$. In order to evaluate the biofilter performance in reducing the emission of ammonia to the environment using different types of filter media mixture. The mix. is a mixture of biomaterial material as a percentage of the total media volume, Mix 1 mixture of 0.25 Conocarpus leaves to 0.75 rice straw, a Mix2 mixture of 0.50 Conocarpus leaves to 0.50 straws of rice, Mix 3 mixture of 0.75 Conocarpus leaves to 0.25 straws of rice.

Distributed 207 birds by 23 birds (14 birds $/ \mathrm{m}^{2}$ ) in each of the nine places. Measurements studied in the first and second experiment:

The efficiency of the biofilter in the treatment of ammonia gas at week 2, 3, 4 and 5 of bird life, using the following equation (Jinanan \& Leungprasert, 2015; Seedorf \& Hartung, 2002).

Where,

$$
\mathrm{RE} \%=\frac{\mathrm{Ci}-\mathrm{Co}}{\mathrm{Ci}} \times 100
$$

Where,

$\mathrm{RE} \%=$ The efficiency of the biofilter in reducing the emission of ammonia

$\mathrm{Ci}=$ concentration of ammonia gas under the biofilter media (ppm)

$\mathrm{Co}=$ Concentration of ammonia gas out of biofilter media (ppm)
The concentration of ammonia gas was measured in the polluted air collected under the biofilter media using the Gas Detection Tube with pump (rang 1-30 pmm , time of one measure is 1-2 minute) made in Drager.com, USA.

Measure the concentration of ammonia gas for air out of the filter (at a height of 50 $\mathrm{cm}$ above the media surface) and by the same device.

Mass mean diameter ( $\mathrm{mm})$ : where eight sieves with different diameters $(75,50,25$, $9.5,4,3.17,1.7,1.18)$ were used after drying the air fill sample, record the total weight and then drain for 5 minutes and then measure the weight of the parts above each sieve using the following equation (Schmid et al., 2004):

$$
\mathrm{dmm}=\frac{\sum \mathrm{mi} \times \mathrm{di}}{\mathrm{M}} .
$$

Where,

$\mathrm{dmm}=$ mass mean diameter $(\mathrm{mm})$

$\mathrm{mi}=$ weight of the parts at each sieve

$\mathrm{di}=$ Midpoint The average between two successive diameters of sieve openings

$$
\mathrm{M}=\text { total weight of the sample }
$$

The measurements also included: density of biofilter media, temperature, moisture content, microbial preparation (total bacteria, total fungi (cfu $\backslash \mathrm{gm})$ ) at 2 and 5 weeks as Harrigan \& McCance (1998).

\section{Statistical Analysis}

The data were analysed for the traits studied using the Completely Randomized Design (CRD) to determine the effect of the different treatments. The differences $(\mathrm{P}<0.05)$ were tested by Duncan (1955). The statistical program SPSS.22 was used for this purpose. 


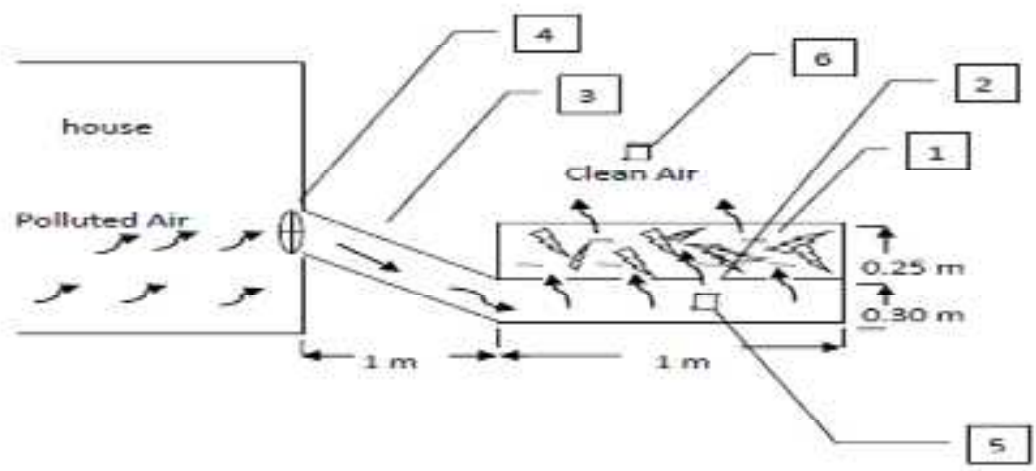

1- Media

2- Perforated barrier

3-Air channel( $\varnothing=0.3 \mathrm{~m})$

4- Fan of ventilation

5-Measurine the concentration of the gas inside

6. Measure the concentration of the outside gas

Fig. (1): Parts of Biofilter and the way insulation with the broiler house.

\section{Result and Discussion}

\section{The first experiment:}

To evaluate the performance of the media of biofilter consisting of a mixture of $30 \%$ Conocarpus leaves to $70 \%$ of the rice straw in the treatment of different concentrations of ammonia gas in the air. Therefore, different densities of birds, 14, 16, 18 (bird / $\mathrm{m}^{2}$ ) were used during the five-week breeding period. The concentration of ammonia under the filter
(Ci) increases with the stocking density, and the statistical analysis showed significant differences between the concentration values of the gas and the effect of bird density. Starting from the second week of the experiment at the age of 14 days for birds and ended at the age of 35 days and this is consistent with Abouelenien et al. (2016) respectively after 45-days of storage.

Table (2): Effect of the stock density on the concentration of ammonia gas outside the bird house, at different ages of birds (average \pm standard deviation).

\begin{tabular}{|c|c|c|c|c|}
\hline \multirow{2}{*}{$\begin{array}{c}\text { Stocki density } \\
\text { bird } \backslash \mathrm{m}^{2}\end{array}$} & \multicolumn{4}{|c|}{$\begin{array}{c}\text { Concentration of ammonia gas under of biofilter media } \\
(\mathrm{ppm})\end{array}$} \\
\cline { 2 - 5 } & 35 days & 28 days & 21 days & 14 days \\
\hline 14 & $25.3 \pm 0.29^{\mathrm{a}}$ & $18.3 \pm 0.29^{\mathrm{a}}$ & $11.7 \pm 0.29^{\mathrm{a}}$ & $6.8 \pm 0.29^{\mathrm{a}}$ \\
\hline 16 & $28.0 \pm 0.00^{\mathrm{b}}$ & $22.0 \pm 1.00^{\mathrm{b}}$ & $14.0 \pm 0.00^{\mathrm{b}}$ & $6.5 \pm 0.50^{\mathrm{a}}$ \\
\hline 18 & $28.8 \pm 0.76^{\mathrm{b}}$ & $23.0 \pm 0.29^{\mathrm{c}}$ & $15.3 \pm 0.29^{\mathrm{c}}$ & $8.7 \pm 0.29^{\mathrm{b}}$ \\
\hline
\end{tabular}

Similar letters mean no significant difference between them $(p<0.05)$. 
Khudher et al. / Basrah J. Agric. Sci., 31 (2): 1-10, 2018

The Fig. (1) of the time series for each stock density shows the results of the efficiency of the biofilter during the time period for running the biofilter and with different densities of birds. Note that the efficiency of the biofilter did not register a significant difference between the values during the period of operation, has maintained an efficiency not less than 91\%. Jinanan \& Leungprasert (2015) that there was no effect on the different concentrations of ammonia gas, which ranged from $0.25-3$ to $20-42 \mathrm{ppm}$. The efficiency of the biofilter reached $99 \%$. We believe that the reason for the improving filter efficiency is due to the increased absorption surface of the polluted and moisture retention where the biofilter media was characterized by an average diameter of $32 \mathrm{~mm}$ parts (Table 3 ), and consequently the total static pressure was reduced and easy to pass the polluted air through the media for treatment.

Fig. (1): Time series of the relationship between different concentrations of ammonia with biofilter efficiency.

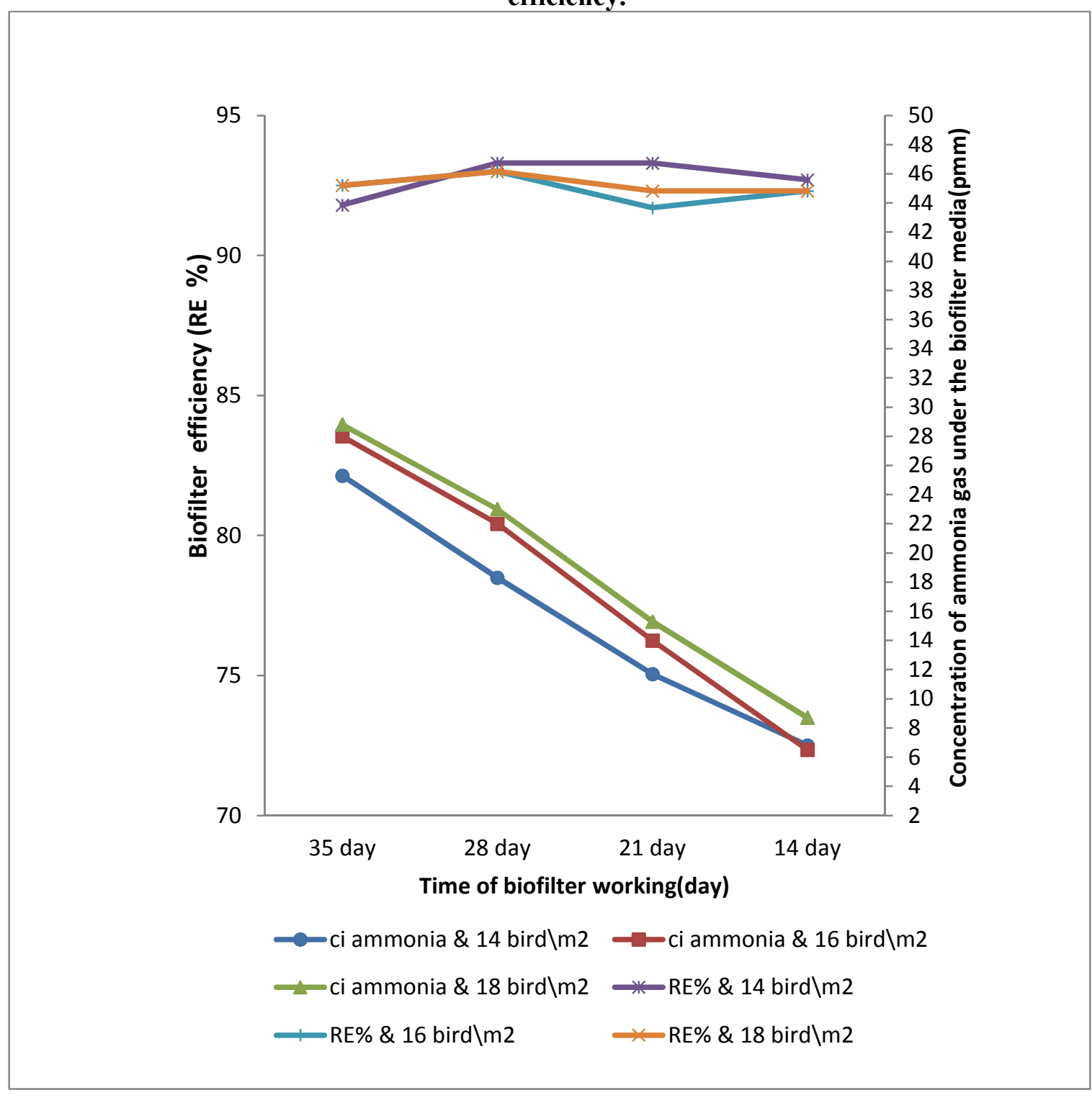


Table (3): Physical properties of bio-filter media (mean \pm standard deviation).

\begin{tabular}{|c|c|c|c|}
\hline Mix. of Biofilter media & $\begin{array}{l}\text { Stock density } \\
\left(\mathrm{Kg} \backslash \mathrm{m}^{3}\right)\end{array}$ & $\begin{array}{l}\text { Mass mean } \\
\text { diameter }(\mathrm{mm})\end{array}$ & Porosity $\%$ \\
\hline Mix & $47 \pm 4.2$ & $32 \pm 0.3$ & $44 \pm 1.6$ \\
\hline
\end{tabular}

Mix of 30 : 0.70 Conocarpus \& rice straw.

\section{The second experiment}

To evaluate the effect of different mixture ratios for the biofilter media (Conocarpus and rice straw) on the efficiency of the biofilter in reducing ammonia emissions to the environment. The results showed in Table (4) that there is a significant effect of the mixing ratios on the efficiency of the biofilter. Mix 1 and Mix2 recorded a better reduction in ammonia emission compared to Mix 3 after 35 days. The efficiency of the filter with Mix 1 was $91.7 \%$ and $91.2 \%$ with Mix2 compared to the efficiency of the filter with Mix 3 which reached $77.5 \%$.

Table (4): Effect of different mixing ratios on the efficiency of the bio filter in ammonia emission reduction and at different operating intervals (mean \pm standard deviation).

\begin{tabular}{|c|c|c|c|c|c|}
\hline \multirow{2}{*}{ Mix } & \multicolumn{5}{|c|}{ Efficiency of the bio filter in ammonia emission reduction (RE\%) } \\
\cline { 2 - 6 } & Avg. & 35 days & 28 days & 21 days & 14 days \\
\hline \multirow{2}{*}{ Mix1 } & $91.7^{\mathrm{a}}$ & $94.3^{\mathrm{a}}$ & $94.3^{\mathrm{a}}$ & $92.3^{\mathrm{a}}$ & $85.67^{\mathrm{a}}$ \\
& $\pm 0.6^{\mathrm{a}}$ & \pm 0.58 & \pm 0.58 & \pm 0.58 & \pm 2.5 \\
\hline Mix2 & $91.2^{\mathrm{a}}$ & $93.0^{\mathrm{b}}$ & $94.0^{\mathrm{a}}$ & $92.7^{\mathrm{a}}$ & $85.0^{\mathrm{a}}$ \\
& $\pm 0.6^{\mathrm{a}}$ & \pm 0.0 & \pm 0.0 & \pm 2.5 & $\pm 0.0^{\mathrm{a}}$ \\
\hline Mix3 & $77.5^{\mathrm{b}}$ & $77.0^{\mathrm{c}}$ & $75.0^{\mathrm{b}}$ & $81.0^{\mathrm{b}}$ & $77.0^{\mathrm{b}}$ \\
& \pm 0.6 & \pm 0.0 & \pm 6.0 & \pm 0.0 & \pm 2.0 \\
\hline
\end{tabular}

We believe that the reason for the disparity in the efficiency of a bio filter in reducing ammonia emissions is due to the effect of mixing ratios on the content of microorganisms growing in the media (bacteria and total fungi) in the second and fifth weeks respectively. Mix1 recorded an increase in the fungus content of $3.03 \times 106$ and $2.85 \times 106 \mathrm{CFU} / \mathrm{gm}$ compared with Mix2 which recorded $1.93 \times 106,1.89 \times 106 \mathrm{CFU} /$ gm and Mix3 which recorded $2.77 \times 106$, $2.70 \times 106 \mathrm{CFU} / \mathrm{gm}$; Oliver (2015) has found an important role for biofilter media in reducing odors and gaseous pollutants. While Mix 3 recorded an increase in bacterial content compared with Mix1 and Mix2 as shown in the table (5).
There are no significant differences between the values of the characteristics (temperature ${ }^{\circ} \mathrm{C}$, moisture content $\mathrm{M} . \mathrm{C} \%$ and $\mathrm{pH})$ according to the mixture ratios of Mix1, Mix2 and Mix3 during the periods of 14, 21, 28 and 35 days (Table 6).

The statistical analysis did not show any significant differences between the values of the physical properties of the three biofilter media (porosity $\%$, mass mean diameter, stock density) (Table 7). 
Table (5): Bacterial and fungi content in biofilter media mixtures (CFU $\backslash \mathrm{gm})$.

\begin{tabular}{|c|c|c|c|c|}
\hline \multirow{2}{*}{ Mix } & \multicolumn{2}{|c|}{ Fungi CFU\gm } & \multicolumn{2}{c|}{ Bacteria CFU\gm } \\
\cline { 2 - 5 } & 14 days & 35 days & 14 days & 35 days \\
\hline Mix1 & $2.85 \pm 6.3^{\mathrm{c}}$ & $3.03 \pm 3.06^{\mathrm{c}}$ & $1.95 \pm 4.2^{\mathrm{b}}$ & $2.45 \pm 5.7^{\mathrm{b}}$ \\
\hline Mix2 & $1.89 \pm 5.0^{\mathrm{a}}$ & $1.93 \pm 2.52^{\mathrm{a}}$ & $1.41 \pm 1.0^{\mathrm{a}}$ & $1.84 \pm 4.0^{\mathrm{a}}$ \\
\hline Mix3 & $2.70 \pm 4.73^{\mathrm{b}}$ & $2.77 \pm 3.51^{\mathrm{b}}$ & $3.46 \pm 2.65^{\mathrm{c}}$ & $4.95 \pm 5.51^{\mathrm{c}}$ \\
\hline
\end{tabular}

The same letters mean that there is no significant difference $(\mathrm{P}<0.05)$.

Table (6): Operation condition of three mixture ratios at 14-35 days $(\mathrm{T}=$ temperature of media biofilter, M.C = Moisture content of media biofilter, $\mathrm{pH}$ value of media biofilter.

\begin{tabular}{|c|c|c|c|c|c|}
\hline \multicolumn{3}{|c|}{ Mix } & $\mathbf{M i x}_{1}$ & $\mathbf{M i x}_{2}$ & $\mathbf{M i x}_{\mathbf{3}}$ \\
\hline \multirow{12}{*}{ 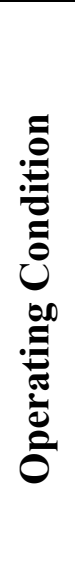 } & \multirow{3}{*}{$\begin{array}{c}14 \\
\text { day }\end{array}$} & $\mathrm{T}$ & $24 . \pm 0.10 \mathrm{a}$ & $24 . \pm 0.06 a$ & $24 . \pm 0.06 \mathrm{a}$ \\
\hline & & M.C & $60.3 \pm 0.60 \mathrm{a}$ & $62.7 \pm 0.58 \mathrm{a}$ & $51.0 \pm 1.00 \mathrm{a}$ \\
\hline & & $\mathrm{pH}$ & $6.4 \pm 0.00 \mathbf{a}$ & $7.7 \pm 0.06 \mathrm{a}$ & $7.4 \pm 0.01 \mathbf{a}$ \\
\hline & \multirow{3}{*}{$\begin{array}{c}21 \\
\text { day }\end{array}$} & $\mathrm{T}$ & $26.2 \pm 0.10 \mathrm{a}$ & $26.7 \pm 0.58 \mathrm{a}$ & $25.9 \pm 0.15 a$ \\
\hline & & M.C & $50.0 \pm 0.57 \mathrm{a}$ & $51.7 \pm 2.00 \mathrm{a}$ & $54.3 \pm 0.58 \mathrm{a}$ \\
\hline & & $\mathrm{pH}$ & $8.1 \pm 0.01 \mathrm{a}$ & $8.3 \pm 0.01 \mathrm{a}$ & $8.1 \pm 0.01 \mathrm{a}$ \\
\hline & \multirow{3}{*}{$\begin{array}{c}28 \\
\text { day }\end{array}$} & $\mathrm{T}$ & $30.5 \pm 0.50 \mathrm{a}$ & $32.3 \pm 0.30 \mathrm{a}$ & $31.7 \pm 0.30 \mathrm{a}$ \\
\hline & & M.C & $50.8 \pm 0.61 \mathrm{a}$ & $51.5 \pm 0.87 \mathrm{a}$ & $52.3 \pm 0.29 a$ \\
\hline & & $\mathrm{pH}$ & $8.1 \pm 0.01 \mathrm{a}$ & $8.3 \pm 0.01 \mathrm{a}$ & $8.2 \pm 0.02 \mathrm{a}$ \\
\hline & \multirow{3}{*}{$\begin{array}{c}35 \\
\text { day }\end{array}$} & $\mathrm{T}$ & $36.2 \pm 0.12 \mathrm{a}$ & $36.9 \pm 0.06 \mathrm{a}$ & $35.3 \pm 0.58 \mathrm{a}$ \\
\hline & & M.C & $51.3 \pm 0.61 \mathrm{a}$ & $51.7 \pm 0.58 \mathrm{a}$ & $50.5 \pm 0.44 a$ \\
\hline & & $\mathrm{pH}$ & $8.2 \pm 0.01 \mathrm{a}$ & $8.3 \pm 0.06 \mathrm{a}$ & $8.2 \pm 0.01 \mathrm{a}$ \\
\hline
\end{tabular}

Similar letters mean no significant difference between them $(\mathbf{p}<0.05)$.

Table (7): The effect of mixing ratios on the physical properties of the media (mean \pm standard deviation).

\begin{tabular}{|l|l|l|l|}
\hline Mix & Stock density $\left(\mathrm{Kg}^{3}\right)$ & Mass mean diameter $(\mathrm{mm})$ & Porosity \% \\
\hline Mix1 & $50.5 \pm 0.5^{\mathrm{a}}$ & $32.3 \pm 0.3^{\mathrm{a}}$ & $42.7 \pm 2.5^{\mathrm{a}}$ \\
\hline Mix2 & $53.7 \pm 0.3^{\mathrm{a}}$ & $28.9 \pm 0.1^{\mathrm{a}}$ & $37.3 \pm 1.5^{\mathrm{a}}$ \\
\hline Mix3 & $72.1 \pm 0.2^{\mathrm{a}}$ & $25.2 \pm 0.3^{\mathrm{a}}$ & $28.7 \pm 1.1^{\mathrm{a}}$ \\
\hline
\end{tabular}

\section{Conclusions}

The first experiment: The efficiency of the biofilter, a mixture of 0.30 Conocarpus Erectus trees, leaves with 0.70 rice straw, was not affected by the concentration of the ammonia gas resulting from differences in bird density. The efficiency of the Biofilter was $91 \%$ during the testing period (14-35) days.
The second experiment: The effect of the difference in the ratio of the mixture of the biofilter materials (the Conocarpus leaves with the rice straw) to the efficiency of the biofilter in reducing the emission of ammonia gas to the external environment. The media were topped with a mixture of 0.25 Conocarpus leaves with 0.75 rice straws on the sides 0.50 Conocarpus leaves with rice 
straw 0.50 and 0.75 Conocarpus leaves with 0.25 straws of rice. The efficiency of the Biofilter was about $91.7 \%$ when media 0.25 leaves of Conocarpus with 0.75 straw, rice during the test period of 14 - 35 days, and characterized by a high content of total fungi compared to the other two.

\section{Acknowledgments}

The authors thank the staff of advisory office in the College of Agriculture, University of Basrah especially Dr. Qutaiba J. Gheni for supporting us with birds and technical assistance; also we thank the staff of Department of Animal Production for laboratory analysis and for Dr. Haider A. AlBataat from Directorate of Basrah's Agriculture for helpful advice relating to Ammonia measurements.

\section{References}

Abouelenien, F.A.; Khalf-Alla, F.; Mousa Balabel, T.; El-Midany, S. \& Nasser, M. A.E.-L. (2016). Effect of stocking density and bird age on air ammonia, performance and blood parameters of broilers. World Vet. J., 6(3): 130-136.

Akdeniz, N.; Janni, K. A. \& Salnikov, I. A. (2011). Biofilter performance of pine nuggets and lava rock as media. Bioresour. Technol., 102(8): 4974-4980.

Carlile, F. S. (1984). Ammonia in poultry houses: A literature review. World's Poult. Sci. J., 40(2): 99-113.

Chen, L. \& Hoff, S.J. (2009). Mitigating odours from agricultural facilities: A review of literature concerning biofilters. Appl. Eng. Agric., 25(5): 751-766.

Chen, L. \& Hoff, S.J. (2012). A two-stage wood chip-based biofilter system to mitigate odours from a deep-pit swine building. Appl. Eng. Agric., 28(6): 893901.

Devinny, J.S.; Deshusses, M.A. \& Webster, T.S. (2017). Biofiltration for Air Pollution Control: C.R.C. Press: 318pp.
Duncan, B.D. (1955). Multiple range and multiple F. Test. Biometrics, 11: 1-42.

Harrigan, W.F. \& McCance, M.F. (1998). Laboratory Methods in Food and Dairy Microbiology. Academic Press: 532pp.

Hoff, S.J.; Harmon, J.D.; Chen, L.; Janni, K. A.; Schmidt, D.R.; Nicolai, R.E. \& Jacobson, L.D. (2009). Partial biofiltration of exhaust air from a hybrid ventilated deep-pit swine finisher barn. Appl. Eng. Agric., 25(2): 269-280.

Hong, J. \& Park, K. (2004). Wood chip biofilter performance of ammonia gas from composting manure. Compost Sci. Util., 12(1): 25-30.

Jinanan, J. \& Leungprasert, S. (2015). The feasibility study of the low cost biofilter to control ammonia from livestock farms. Int. J. Res. Chem., Metallurgical Civ. Eng., 2(1): 1-8.

Kim, N.-J.; Hirai, M. \& Shoda, M. (2000). Comparison of organic and inorganic packing materials in the removal of ammonia gas in biofilters. J. Hazard. Mat., 72(1): 77-90.

Kostadinova, G.; Petkov, G.; Denev, S.; Miteva, C.; Stefanova, R. \& Penev, T. (2014). Microbial pollution of manure, litter, air and soil in a poultry farm. Bulg. J. Agric. Sci., 20: 56-65.

La Pagans, E.; Font, X. \& Sánchez, A. (2005). Biofiltration for ammonia removal from composting exhaust gases. Chem. Eng. J., 113(2-3): 105-110.

Lawniczek-Walczyk, A.; Gorny, R.L.; Golofitit, S.M.; Niesler, A. \& Wlazlo, A. (2013). Occupational exposure to airborne microorganisms, endotoxins and Bglucans in poultry houses at different of the production cycle. Ann. Agric. Environ. Med., 20: 259-268.

Lim, T.-T.; Jin, Y.; Ni J.-Q. \& Heber, A.J. (2012). Field evaluation of biofilters in reducing aerial pollutant emissions from a commercial pig finishing building. Biosyst. Eng., 112(3): 192-201. 
Maia, G.D.; Gates, R.S. \& Taraba, J.L. (201). Ammonia biofiltration and nitrous oxide generation during the start-up of gas-phase compost biofilters. Atmos. Environ., 46: 659-664.

Nicolai, R.E.; Clanton, C.J.; Janni, K.A. \& Malzer, G.L. (2006). Ammonia removal during biofiltration as affected by inlet air temperature and media moisture content. Trans. ASAE (Am Soc Agric Eng), 49(4): 1125-1138.

Nicolai, R. \& Janni, K. (2001). The Biofilter media mixture ratio of wood chips and composts treating swine odours. Water Sci. Technol., 44(9): 261-267.

Ogink, N. \& Koerkamp, P.G. (2001). Comparison of odour emissions from animal housing systems with low ammonia emission. Water Sci.Technol., 44(9): 245252.

Okoli, I.; Alaehie, D.; Akanno, E.; Okoli, C; Opara, M.; Uchegbu, M. \& Lheukwumere, L. (2004). Concentrations of aerial pollutant gases in selected poultry pens in Imo state, Nigeria. Int. J. Poult. Sci., 3(6): 427-431.

Pagans, E.; Font, X. \& Sánchez, A. (2007). Coupling composting and biofiltrationfor ammonia and volatile organic compound removal. Biosyst. Eng., 97(4): 491-500.

Prokop, W.H. \& Bohn, H.L. (1985). Soil bed system for control of rendering plant orders. J. Air Pollut. Control Assoc., 35(12): 1332-1338.

Ryu, H.W.; Cho, K.-S. \& Lee, T.-H. (2011). Reduction of ammonia and volatile organic compounds from food waste-composting facilities using a novel anti-clogging biofilter system. Bioresour. Technol., 102(7): 4654-4660.

Schmid. D; Janni, K. \& Nicolia, R. (2004) . Biofilter Design Information. (Vol. BAEU18), Univ. Minnesota Ext., Dep. Biosyst. Agric. Eng., Coll. Agric. Food Environ. Sci.: $25 \mathrm{pp}$.

Seedorf, J. \& Hartung, J. (2002). Reduced efficiency of a container-based biofilter for bioaerosols from a broiler house. Anime. Prod. Aust, 24: 205-208 .

Williams, C.M.; Barker, J.C \& Sims, J.T (1999) Management and utilization of poultry wastes Tables 2,3,4,5,6 and 7. Rev. Environ. Contam.Toxicol.,162: 105-157.

Yang, L.; Wang, X.; Funk, T. \& Gates, R. (2011). Biofilter media haracterization and airflow resistance test. Trans. ASAE (Am. Soc. Agric. Eng.) 54(3): 1127-1136. 